\title{
The Approach of Shura in Rachid Ghannouchi's Conception of the State
}

\section{Hafijur RAHMAN ${ }^{1}$}

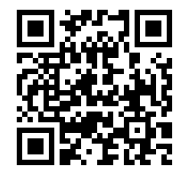

\begin{tabular}{ccc}
\hline $\begin{array}{c}\text { Geliş Tarihi/ Received } \\
\text { 14.10.2020 }\end{array}$ & Kabul Tarihi/ Accepted & Yayın Tarihi/ Published \\
Citation/Atıf: Rahman, H., (2021), The Approach of Shura in Rachid Ghannouchi's \\
Conception of the State, Atatürk Üniversitesi İktisadi ve İdari Bilimler Dergisi, 35(3): Sayfa: \\
879-899, https://doi.org/10.16951/atauniiibd.810652
\end{tabular}

Abstract: This research analyzed the approach of Shura in the political thought of Rachid Ghannouchi, one of the prominent Muslim scholars in the contemporary world. Ghannouchi intended to argue Shura as an essential principle of the Islamic state after text (Nass), even more important because of the interpretation and implementation of text also depends on Shura. Following this aspect, Shura is the fundamental element for the formation of the state and its legislations. By the term Shura, he didn't mean the consultation with only the Ulama but the entire Ummah, where he considered Ummah is the legitimate authority of the Islamic state. After the Arab Spring, Ghannouchi's political thought and politics are crucial topics in academia. Within several transformations in politics as an aftermath of the Arab Spring, Ghannouchi now argues for a Muslim democratic state. This research considered the term Shura as the keyword of Rachid Ghannouchi's conception of state.

Keywords: Ghannouchi, Shura, Ummah, Islamic State, Muslim Democratic State, Arab Spring

\section{Raşid Gannuşi’nin Devlet Anlayışında Şura Yaklaşımı}

Öz: Bu araştırma, çağdaş dünyanın önde gelen Müslüman aydınlardan biri olan Raşid Gannuşi'nin siyasi düşüncesinde Şura yaklaşımını analiz etmektedir. Gannuşi, metinden (Nass) sonra Şura'yı Íslam devletinin temel ilkesi olarak tartışmayı amaçlamış hatta metin en önemli ilke olması bile metnin yorumlanması ve uygulanması nedeniyle Şura'ya bağlıdır. Bu görüşü takiben, Şura, devletin ve kanunlarının oluşumunda temel unsurudur. Şura terimiyle, yalnızca Ulema ile danışma içinde olmayı değil, İslam devletinin meşru otoritesi olarak gördüğ̈̈ tüm ümmetle istişare etmeyi kastetmiştir. Arap Baharl'ndan sonra, Gannuşi'nin politik düşüncesi ve siyaseti akademik dünyada kritik yer tutmaktadır. Arap Baharı'nın ardından siyasette yaşanan birçok dönüşümde, Gannuşi, Müslüman demokratik bir devleti savunmaktadır. Bu araştırma, Şura terimini Raşid Gannuşi'nin devlet anlaylşının anahtar sözcügü̈ olarak kabul etmektedir.

Anahtar Kelimeler: Gannuşi, Şûra, Ümmet, İslam Devleti, Müslüman Demokratik Devleti, Arap Baharl

JEL Codes: F50, H70, N45, Z12

${ }^{1}$ Asst. Prof. Dr., Tokat Gaziosmanpaşa University, Department of Public Administration, hafijdu@gmail.com, https://orcid.org/0000-0001-7945-6307 


\section{Araştırma problemi}

\section{GENIŞLETILMIŞ ÖZET}

$\mathrm{Bu}$ araştırma, Raşid Gannuşi’nin Şura terimine yaklaşımını ve Şura'ya dayalı bir devleti nasıl savunmayı istediğini incelemeyi amaçlamaktadır.

\section{Araştırma soruları}

Bu araştırma, amacına ulaşmak için ilk olarak, Gannuşi'nin Şura terimine nasıl yaklaştığını ve ikinci olarak, Arap Baharı'ndan sonra Müslüman demokratik devletinde Şura yaklaşımı nedir? olmak üzere iki araştırma sorusu belirlemeyi hedeflemiştir.

\section{Literatür Taraması}

Bu kısım, mevcut literatürde, Şura terimi ve Gannuşi'nin Şura terimine nasıl yaklaştığına dair yaklaşımları incelemeyi amaçlamıştır. Şavit (2010), Whyte (2019) ve Okumuş (2019) klasik ve çağdaş Müslüman filozofların yazılarında Şura'ya yaklaşımı önemli ölçüde analiz etmişlerdir. Şura'nın imam seçmede önemli bir rol oynadığı yerde, El- Maverdi, ilk kez halifeliğe bir alternatif olarak İmamet kavramını savunan ilk Müslüman âlimlerden biriydi (al-Mawardi, 1996: 3-5). Nizamül Mülk ve İbn Teymiyye, devlette Şura'yı önemli ölçüde tartışan çok önemli Müslüman âlimlerdir (Whyte, 2019; Mulk, 1960; Ibn Taymiyyah, 2020). Çağdaş zamanlarda Müslüman aydınlar, Moden devletinin kavramını, özellikle de demokrasi ve Şura arasında köprü kurmayı amaçlamışlardır. Pan-İslamcı ve Genç Osmanlı aydınlar bu perspektiften tartışmışlardır (Hourani, 1983: 75; Black, 2011: 283; Tamimi, 1997). Cemaleddin Afgani ve Muhammed Abduh, Müslümanların modernite kavramına yaklaşmaları gerektiğine inanmışlar ve bu nedenle Şura içinde demokratik bir sistemi savunmuşlardır (Tamimi, 1997: 4; Landau, 1994: 32; Black, 2011: 293). Bununla birlikte, Raşid Rıza ve Abduh, Ulema'nın Şura'yı uygulamaktan veya Şura olarak çalışmaktan sorumlu olduğunu iddia etmişlerdir (Enayet, 1982: 77). İslamcı aydınlar, özellikle Ebu'l A'lâ el-Mevdudî, Şura'nın İslam devletindeki önemini ortaya koymuş ve bunu Modern zamandaki parlamenter sistemle karşılaştırmışlardır (Black, 2011: 309). Hasan al-Benna ve Seyyid Kutb da Şura'yı İslam Devleti'nin en önemli ilkesi olarak savunmuştur (el-Ghazali, 2011: 337; Qutb, 2013: 151). Onlar1 takiben Bennabi, Turabi (1983) ve Karadavi (2004) de bir İslam devletinde Şuranın önemi savumuştur. Bununla birlikte, Gannuşi'nin şura yaklaşımı, modern devlet sistemi ile kıyasladığında sistemik ve cesur bir yaklaşım olduğunu görebiliriz.

Akademideki bu konuda mevcut araştırmalarda, Gannuşi'nin siyasi düşüncesini ve Şura algısını önemli ölçüde analiz edilmiştir. Tamimi'nin (2001) başyapıtı "Rachid Ghannouchi: A Democrat within Islamism" kitabı bu konuda önemli çalışmalardan biridir. Tamimi, Gannuşi'nin demokrasiye giden yolculuğunu Şura algısına göre olduğunu belirtmiştir. Wolf (2013; 2017), Göksel (2014), Cavatorta \& Merone (2015), McCarthy (2015), Kaya (2018), Marzo (2019) ve diğer birçok araştırmacı aynı şekilde araştırma yapmıştır ve onun siyasi düşüncesinin çeşitli yönlerini ve özellikle Arap Baharı sonrası 
Ennahda'nın siyasetini tartışmışlardır. Ancak Okumuş'un (2019) tezi bu çalışma için daha alakalıdır. Okumuş (2019) Şura terimini demokrasi, yani Müslüman demokrasisi ile ilişkilendirmeyi amaçlanmıştır.

\section{Yöntem}

$\mathrm{Bu}$ araştırma, hem birincil hem de ikincil verilere dayalı nitel bir araştırmadır ve veri analizi için kapsamlı bir şekilde içerik analizi yöntemini kullanılmıştır.

\section{Bulgular ve Sonuçlar}

Gannuşi, devlet anlayışını tanımlamak için Şura'yı merkeze koymuştur. Şura'yı devletin en önemli prensibi olarak tanımlamıştır. Bu yönüyle devletin oluşumu, yasama ve diğer birçok temel ilkeleri Şura'ya bağlıdır.

\section{Introduction}

The term Shura is a crucial topic in Islamic political thought. Both early and contemporary Muslim scholars paid their attention to the topic. Shavit (2010), Whyte (2019) and Okumuş (2019) significantly analyzed the aspect of Shura in the writing of classical and contemporary Muslim philosophers. AlMawardi was one of the early Muslim scholars who argued for Imamate as an alternative to the caliphate for the first time where Shura (ahl al-hall wa-al'aqd) plays a significant role in electing the Imam (head) of the state (alMawardi, 1996: 3-5). Nizamul Mulk and Ibn Taymiyyah were crucial Muslim scholars who significantly argued for Shura in the political authority, i.e. state (Whyte, 2019; Mulk, 1960; Ibn Taymiyyah, 2020). In contemporary times, Muslim scholars intended to bridge the Moden state's concept, particularly the democracy and the Shura. The Pan-Islamic scholars, along with the Young Ottoman scholars, argued from this perspective (Hourani, 1983: 75; Black, 2011: 283; Tamimi, 1997). Jamal Uddin Afghani and Muhammad Abduh believed that Muslims should approach to the concept of modernity. They argued for a democratic system within the Shura (Tamimi, 1997: 4; Landau, 1994: 32; Black, 2011: 293). However, Rashid Rida and Abduh argued that Ulama is responsible for implementing the Shura or work as Shura (Enayet, 1982: 77). The Islamist scholars, notably Abul Al'a Maududi, put Shura's significance in the Islamic state and compare it with the parliamentary system in Modern time (Black, 2011: 309). Hassan al-Banna and Qutb also argued Shura as the vital principle of the Islamic State (el-Ghazali, 2011: 337; Qutb, 2013: 151). Following them, Bennabi (Zoubair, 1998), Turabi (1983), and Qaradawi (2004) also empathized on Shura. However, Ghannouchi's approach to the concept of Shura is systemic and bold in terms of the modern state by comparing the democratic system (Rahman, 2021a).

Existing research in academia significantly analyzed Ghannouchi's political thought as well as his perception of Shura. Tamimi's (2001) masterpiece "Rachid Ghannouchi: A Democrat within Islamism" is one of the important studies here where the title of the book itself indicates his intend. He 
significantly put Ghannouhi's journey toward democracy, though the perception of Shura didn't get any special intention where he analyzed this issue as general to discuss Ghannouchi's political thought. Wolf (2013; 2017), Göksel (2014), Cavatorta \& Merone (2015), McCarthy (2015), Kaya (2018), Marzo (2019), and many other researchers forwarded in the same way where they discussed several aspects of his political thought and Ennahda's politics after the Arab Spring in particular. However, Okumuş's thesis (2019) comparatively more relative to this study where he intended to discuss the approach of Shura in both the Muslim Brotherhood (al-Ikhwan) and Ennahda's political thought. Apparently, his analysis focused on the issues i.e. politics of these two movements as a ruling party after the Arab Spring. He intended to relate the term Shura with democracy, i.e. Muslim democracy.

This research considered the term Shura as the keyword to understand Ghannouchi's conception of state which means more than being simply a tool of Muslim democracy. However, in many aspects it is analyzed as an important tool of Muslim democracy but Ghannouchi intended to understand more. According to Ghannouchi, Shura is the fundamental principle of state in Islamic political thought after the text (Nass). Ghannouhci discussed different aspects of Shura in the Islamic state. In legislative aspect Shura is the most crucial element for legislation. In the political aspect, Shura is the vital element to the birth of the state. Within Shura, Ghannouchi intended to respond many contemporary issues of the Islamic state, which become controversial in Muslim scholars' writing, particularly the participation of women in the legislative council, the participation of non-Muslim, and so on. However, his politics transformed in many ways as an aftermath of the Arab Spring, but Shura remains a vital element.

The current research intended to discuss the approach of Shura in Rachid Ghannouchi's political thought. This research is a qualitative form research based on both primary and secondary data. For data analysis, it extensively used the content analysis method. In academia, content analysis analyzes the text, verbal and visual communication massage for understanding the writer and sender's real message. It aims to build a model to describe the phenomenon in an abstract form (Elo and Kynga, 2008: 107). Krippendorff defined content analysis as "a research technique for making replicable and valid inferences from texts (or other meaningful matter) to the contexts of their use" (Krippendorff, 2004: 18). The content analysis of Ghannouchi's perception of shura and his others writing as primary data and other secondary data used in this research focusing the term Shura intended to analyze the approach of Ghannouchi to the term Shura.

\section{An Intellectual and Political Biography of Rachid Ghannouchi}

Rachid Ghannouchi (also spelled as Rachid al-Ghannouchi or Rashid alGhannoushi) was born in 1941. His family was religious lived in the Tunisian province of Gabes, where he memorized the Quran at an early age. He 
completed high school level from al-Zaituna, a traditional Islamic institution in Tunisia, later completed his Bachalor's degree from the University of Damascus, Syria (Department of Philosophy). He completed his postgraduation degree from Sorbonne, Paris, with the thesis, The Quranic Approach to Education. After returning to Tunisia in 1969, he started his career as a philosophy teacher in a high school (Tamimi, 2001: 33).

Ghanouchi wrote several crucial books, articles, research papers and so on. His masterpiece Al-Hurriyat al-'Ammah Fid-Daivlah al-lslamiyyah (Public freedoms in the Islamic state) is considered one of the most important reference books in contemporary Islamic political thought. Along with this book, he wrote several books as Laiklik ve Sivil Toplum (Secularism and civil society), AlDimuqratiyyah wa Huquq Al-Insan fi Al-Islam (Democracy and Human rights in Islam), İslami Yöneliş (Islamic resurgence), Kur'an ve Yaşam Arasında Kadın (Women between Quran and practical life), Islam toplumunda Vatandaşlık hakları (Citizenship rights in Islamic society), Secularism in the Arab Maghreb and The participation of Islamist in a Non-Islamic Government. In intellectual trend, he was influenced by Algerian intellectual Malik Bennabi. In studying postgraduation in France, he met with Malek Bennabi when he traveled to his home through Algeria (Tamimi, 2001: 28). Later, He met several times with Bennabi, which influenced him to develop his intellectual and political thought. Along with Bennabi, Ghannouchi was also influenced by the intellectuals of Magrib. In the perspective of Mashriqhi intellectual, he was also influenced by Maududi, Banna, and Khomeini though his thought was different in many topics. He often criticized Sayyid Qutb in his writing. He accepted the thoughts of Turabi, particularly the women participation in politics (Rahman, 2021a: 154, Rahman, 2021b).

Along with the intellectual life, Ghannouchi has a vast political experience. He was influenced by the politics from his early ages, particularly by his maternal uncle who was a great supporter of Arabism, i.e., Nasserism, initiated by Gamal Abdel Nasser of Egypt (Tamimi, 2001: 5-6). His attraction to Arabism fell when he came to Egypt for his undergraduate study before going to Syria. However, he couldn't continue there because of the political problem. As a result he got the chance to see the inner side of Nasserism directly and claimed that it was just a slogan based; the people were dissatisfied with him, i.e. President Nasser (Tamimi, 2001: 15). His attention toward the Islamic movement was drawn in the time of Damascus when he was in touch of a prominent Islamic scholar Professor Adib Salih who was a lecturer of the Shari'a college at the University of Damascus and a publisher of the monthly periodical called Al-Hadarah al-Islamiyah (Islamic civilization) that was established by Dr. Mustafa as-Siba'i, the founder of the Muslim Brotherhood in Syria. Tamimi mentioned that Ghannouchi was so impressed by this prestigious publication and described himself as unmatched by any other Islamic publication he has ever come across (Tamimi, 2001:19). In the last two years of 


\section{The Approach of Shura in Rachid Ghannouchi's Conception of the State}

Damascus, he read some writings of Muhammad Iqbal, Maududi, al-Banna, Sayyid Qutb, Muhammad Qutb, as-Siba'i, Malik Bennabi, and an-Nadwi. Besides the Muslim Brotherhood, he also gained experience from the Sufi orders, Hizb-ut-Tahrir al-Islami, and the Salafiyah though he didn't join any movement at that time. In the time of Paris, he engaged with Tablig Group (Tamimi, 2001: 24-25, Rahman, 2021b).

$\mathrm{He}$ is the founder of the Ennahda party, the largest Islamist party in Tunisia. Here, it is need to elaborate a little bit the journey of Ennahda party to understand the aspect of Ghannouchi's political experience. After returning from France, Ghannouchi intended to observe Tunisia's whole situation and environment for implementing his mission toward Islamic politics. In 1970, he organized a small group as Al-Jama'ah al-Islamiya (The Islamic Group) as a secret or underground organization because of the authoritarian government's prohibition to organize this kind of organization. For instance, the authoritaians and autocrates ruled Tunisia from its independes to the Arab Spring. However in 1981, he established the Islamic Tendency Movement (MTI in short according to its French acronym) within the chance of government declaration for allowing the formation of a political party. MTI later change by the name of the Ennahdah Party (the Renaissance Party, in the original name; Hizb alNahdah) in 1988 because of the government regulation for the prohibition of the establishment of political parties on confessional, ethnic, racial, or regional bases. He has been imprisoned for the times of 1981-84 and 1987-88. In 1989, after the general election under the occupied ruler Zine El Abidine Ben Ali, Ennahda had emerged as significant opposition and securing $14.5 \%$ of the vote as an independent candidate (Esposito and Piscatori, 1991). However, all the opposition parties' combined total vote showed less than five percent in the official declaration under the law no. 88-32. It was a significant threat to the ruling regime emerging of Ennahda in the popular vote. As a result, the regime announced the Ennahda as illegal because the election authority rejected their application for registering as a political party. Many of the party members punished by five years' imprisonment, Ghannouchi traveled into voluntary exiled in London in the same year. He lived there till the fall of autocratic president Zine al-Abidine Ben Ali in 2011 due to the popular uprising, which has been named as the Arab spring. In the general election in 2011, his party gained majority seats in the parliament and form a coalition government. However, after two years, they resigned and announced an early election because of the economic crisis and peoples' protest. In 2014, they become major opposition though their participation in government was continued with mutual understanding with minor participation. In the election of 2019, his party again gained the majority seats though it was far from absolute majority, so again a coalition government was inevitable. After the election, he elected as the speaker of parliament and, till now he is serving in this vital post (Rahman, 2021b). 


\section{Ghannouchi's Conception of the State}

Ghannouchi mainly discussed his conception of the state in the book "alHurriyat al-'Ammah Fid-Daivlah al-lslamiyyah (Public freedoms in the Islamic state)." This research studied the Turkish version of the book, "Islam Devletine Kamusal Özgürlükler". This book is divided into four main sections, where he discussed three main issues regarding the Islamic state. Firstly, he discussed the concept of freedom and human rights in Islam, secondly, the status of democracy in Islam, and finally, the concept of the Islamic state. Within these three main issues, he intended to discuss his concept of state. This research broadly discusses his thoughts regarding the principles of the Islamic State, which he discussed in chapter four in an extended way and empathized with a Shura-based Islamic state.

\subsection{Western perspective of State}

Without entering extended philosophical debate and deep historical background, Ghannouchi intended to summarize the characteristics of the Western perspective of state. He started by searching the relation between law and religion in the West. According to him, religion is a crucial issue in every civilization, and men were surrendering themselves to God at an early age (Ghannouchi, 2015: 98). Following this perspective, laws first come from religion by the Prophets within divine order (Wahy). Later, the autocratic rulers started to establish them in the apex of power and kept in mind that they are the shadow of God, even stating, "I am the state, I am the shadow of God on earth" (Ghannouchi, 2015: 98). They started to generate the laws as they wished, and the religious leader supported them. Sometimes the religious leader intended to establish them in place of God in terms of generating law. Notably, the kings and popes oppressed the European people in every aspect of life. Ghannouchi paid his attention to this point and stated that Western stated is based on two essential characteristics; legitimacy and sovereignty (Ghannouchi, 2015: 99).

He considered legitimacy is a central appraisal of the modern state. The authority should follow the existing laws and regulations; if they don't follow the laws, they should be punished by the judiciary. In addition to this, it has to follow the fundamental values and supreme objectives of the society. Finally, the state has to ensure that its functions should be taken on behalf of people's interests, necessity, and acceptance regarding legislation and execution.

On the other hand, he considered sovereignty is another central approach of the modern state. He stated that sovereignty is the high authority of the state, especially in terms of law formation and no authority over the state. It is a high authority from any authority of the state. He intended to mean the kings and popes that they cannot supreme over the state.

\subsection{Islamic Perspective of State}

Ghannouchi started by arguing about the aspect of state in Islam. According to him, Islam is a comprehensive religion from all aspects, i.e., 
religious, political, economic, cultural, moral, and social aspects. He quoted from the Philosopher Muhammad Iqbal, "You can look in Islam as a religion in a perspective and other perspectives it is as a state" (Ghannouchi, 2015: 115). He stated that the existence of the state in Islam is settled by the consensus (Ijma) of Islamic Jurists. He further stated that only a small group of Mu'tazila and Khariji opposed it where they claim that politics is not obligatory though they also got used to make politics in their works. He claimed that the influence of Western thoughts in Muslim countries and the Imperialist education system encourages the concept of secularism i.e. separation of religion and politics. Within this way, a number of Muslim intellectuals intended to adapt to the secular state in Muslim countries. He mentioned the name of Ali abd-Razzak and his book as an example of his claim. Further, he also mentioned the names of other Maghrebi intellectuals who also claimed the separation of religion and politics and intended to prove that Islam has no political matter. Within this context, Ghannouchi intended to provide some proof in favor of the Islamic state from history, text, and consensus. He mentioned the context of political authority in Medina and its following. He stated many verses of the Quran and Sunnah by which prove the existence of an Islamic state or describe its necessity. He also mentioned the consensus (Ijma) of Ulama in favor of the existence of an Islamic state.

\subsection{The principles of an Islamic state}

Ghannouchi intended to identify two obligatory principles of an Islamic state as the text (Nass) and the Shura (Ghannouchi, 2015: 128). These two principles are the most important aspects of Ghannouchi's political thought toward the Islamic state.

\section{A. Text (Nass)}

Ghannuchi argued that the first source of legitimacy in Islam is the text or divine revelation as the Quran and Sunnah. By mentioning several verses of chapters of the Quran where Allah ordered to implement his law in the governing and warned who denies it and mentioning the hadiths where Prophet stated that the fundamental source of legislation is the Quran and Sunnah, Ghannouchi intended to prove that Islam has a governing system and this system has been provided by Allah. Muslims should obey Allah as the supreme source of law. He included that no law can be supreme in front of these texts and without any kind of debate the real Authority (sovereignty) is on behalf of him, Allah. He quoted several theorists as Sayyid Qutb, who described that denying this authority is the cause of big sin and big sin is the cause of being non-believer (Kafir) as the opinion of Khariji. Here, the Scholars of fiqh and Tafsir (Jumhur Fukaha and Mufassir) are opposing to this opinion, in their opinion who will deny to role according to the text he will be Fasiq and Zalim. Finally, he argued that text is the basic foundation of the government. Within this viewpoint, Allah is the real owner of the authority. He is the high authority 
in terms of society, life and existence. There is no controlling authority above God's authority (Ghannouchi, 2015: 136-140).

B. Shura

According to Ghannouchi, Shura is the second principle of the Islamic governing system after text; in fact, most essential principles in terms of interpreting text and source of legitimacy (Ghannouchi, 2015: 141). Because the implementation of the text depends on Ummah (Muslim community) as the vicegerent of Allah. Here legitimacy doesn't depend on any particular person, but entire Ummah. The Ummah implements the power of legitimacy by Shura. Here Ghannouchi didn't mean only the general meaning of Shura (counsel, consultation) but intend to mean more. In his book, he wrote about one-third of the pages only on Shura. So, Shura is the central discussion point of his thought.

At first, he mentioned several verses from the Quran and several hadith where Allah and his Prophet stated to accomplish work with consultation (Shura). As he mentioned from the chapter al-i Imran, "Consult them in the matter. And when you have decided, then rely upon Allah. Indeed, Allah loves those who rely [upon Him]" (as translated by The Noble Quran, 2016, 3: 159). By mentioning that verse and several hadiths, he intended to prove that Shura is the obligatory element to accomplish all of the work of Muslims, which may be small or big; it may be done by the president or officer. It is the symbol of the Islamic state and Ummah. He further argued that Shura is not only a matter of one-two verses of the Quran or some hadith, but it is the fundamental principle of Islam. It ensures the participation of Muslims in the legislation and execution of the Islamic state. Ghannouchi here mentioned four crucial aspects of implementing Shura as legislative, political, educational, and cultural.

\subsubsection{Legislative Aspect of Shura}

Ghannouchi mentioned the verse of the chapter Nisa of the Quran, where Allah ordered to obey Allah, Prophet, and the Ulil Amar (authority). He mentioned the verse, "O, you who have believed obey Allah and obey the Messenger and those in authority (Ulul A'mar) among you" (as translated by The Noble Quran, 2016, 4: 59). He argued that this verse is the basic text of the political, social and religious context of Islam. He mentioned the argument of Imam Shafi'i where he argued that, if any verse of the Quran regarding state wouldn't descend, this verse is enough to prove the governing system in Islam (Ghannouchi, 2015:142). By mentioning the opinions of theorist and Ulama, Ghannouchi argued that by authority (Ulul A'mar) described in the verse of 59 in the chapter of Nisa mean the state/public authority (government) because this verse indicates the theory of society and state (Ghannouchi, 2015: 142-143). He stated that the obeying of Ulil Amar is a conditional matter where the obeying of Allah and his Prophet is without any condition. 


\section{The Approach of Shura in Rachid Ghannouchi's Conception of the State}

Ghannouchi further intended to identify the relation between Shura and Ijma (consensus). He stated that the Prophet didn't announce his successor in his lifetime, and after his death, his companions elected Abu Bakar as his successor (caliph) within the method of Ijma. After that, in many aspects, Ijma has become the most crucial element for resolution. $\mathrm{He}$ argued that the caliphate was established based on Ijma and continued till the monarchial type of government which followed the Sasanian culture of the throne. He also included that in the early years of Islam, Ijma was an essential element in society for resolving where the text didn't provide a clear-cut message. Ghannouchi mentioned several examples from the hadith, where the Prophet stated the importance and the aspect of Ijma. Finally, he intended to establish that Ijma has opened the door of Shura and Ijtihad.

$\checkmark$ Who is responsible for legislation in the Islamic state?

Ghannouchi argued the responsibility of legislation in the Islamic State belongs to the Ummah through Shura. This Shura will accommodate the laws within the text and Ijma (if necessary, especially where the text is unavailable). He started with the line, by consensus of Muslims, the primary source of legislation belongs to Allah. Later he paid his concern, where the direct role is the absence in the Quran or hadith, who will be responsible for legislation? Is it the function of the whole Ummah or the elected representative or the Ulama who have the quality to make Ijtihad?

Firstly, he targeted the classical jurists who argued that the responsibility of legislation in terms of Ijma would depend on Ulama because only the Ulama is permitted for Ijtihad, not the general people. He argued that although the Ulama is the expert of text but legislation is not only means the debate and the findings of the solution of the problems from the text, but it is broader, often it is the matter of negotiation with civil societies, trade unions, and the federations. He further argued that whatever the level of knowledge is of a particular one, it will be unlawful to decide by a fixed group in the name of Ummah (Ghannouchi, 2015: 152-153). Where text is unavailable, especially the economic and social aspect of Ummah or the aspects of war, peace, and education, it is necessary to decide the whole Ummah within the context of Shura. He stated from Hasan al Banna to the contemporary period, the Islamic movement accepted the modern parliamentary system based on representation is near to the Islamic system (Ghannocuhi, 2015: 153).

Secondly, Ghannouchi intended to identify three ways to work Shura; firstly, The Ummah can do it by direct election or referendum for important decisions like the election of the head of state or members of the Shura, making deals with another country in foreign affairs; secondly, the expert body (Ahlul $H a q$ wal-Aqd) can perform it as proxy (vekalet) from Ummah who has knowledge and experience in their field. They can make a Shura body to perform their work as auditing and controlling the work of government; thirdly, 
the Ulama can perform it for auditing the work of government to maintain the Sharia law (Ghannouchi, 2015: 154-161).

\subsubsection{The Political Aspect of Shura}

After discussing the legislative aspect of Shura he concerned about the political aspect of Shura. He argued that Shura is a basic element of the birth of an Islamic state. Here, he discussed broadly on this issue. At first, he discussed the general perspective of the birth of state that according to him, one of the more crucial issues in political science. He started his discussion with mentioning two general perspectives of the birth of state in political thought,

- By coercion

In this process, a leader or king is forcing to make a submission to him and subject to fulfill his will. In this process, the winner/ the king are making law according to his own will. Several states have established as a result of war and the winning leader has become the head of the state.

- By contract

It is a contract between the citizen of the state to come under the authority with liberties and freedom. In this process, they once lived under the law of nature and then the come under one umbrella because of needing some cooperation with others as a social man. They come together with a condition of remaining their liberties and freedom.

$\checkmark$ Imamate is a contract

He argued that imamate is a contract between Imam and Ummah (Ghannouchi, 2015: 186). Here he quoted from as-Senhuri's thesis (La Califat, published in 1926) where he argued that Imamate is a contract between two groups; Imam and Ummah (Ghannouchi, 2015: 186). He also quoted from Ziauddin Ar-Rais where he stated that the contract of Imamate in Muslim community is further advance than Rousseau's social contract (Ghannouchi, 2015: 186).

Ghannouchi further argued that the Imam has gained the power of authority only by this contract and it should be by mutual understanding. It isn't differing if Imam himself becomes a Mujaddid, because without Ijma or majority's support, the Ijtihad of Imam doesn't work. Here Ghannouchi argued that due to this aspect, the Islamic government is a democratic one.

Further, Ghannouchi stated that Prophet seeking $B a^{\prime} y a h$ (oath) from the Aws and Khajraj to establish an Islamic government in Media. He mentioned that the example of electing Abu Bakar as a caliph is providing a clear message on this issue. His throne speech is important here. The Ummah has become his check and balanced authority that has the right to correct him if he did wrong. Abu Bakar showed the example of becoming caliph in the oath ceremony. This Biyah has been performed in the Mosque where everybody (mass people) participated. 
So, imamate is a contract and $B a^{\prime} y a h$ is the symbol or medium of this contract. There is no other way of becoming Imam without this contract (Ghannouchi, 2015: 187). In this way, Imam could be elected and this system work through Shura, make obligatory to listen to the advice and counsel of Ummah. Only because of contract, people can obey the Imam. So, Imamate is the will of Ummah. Ummah has sovereignty over Imam. Here all of this process must be implemented through a constitutional process i.e. with legal framework (Ghannouchi, 2015: 187-188).

Along with this discussion, Ghannouchi intended to discuss three important perspectives regarding this "contract" issue which are raised as question in several time; (1.) the Shia ideology; (2.) contract is not mean the legislation but ruler; (3.) state is the necessity of human society (Ghannouchi, 2015: 188-195).

Firstly, he stated from Shia's ideology where Imamate is the position of divinity and opposing Imam is meaning the opposing of God. In an extension meaning, Imamate is a divine matter not the work of Dunya (existing life). They also believed that revolt to Imam means the revolt to Allah as like doing Shirk with Allah which is a big sin. This concept is also available in the constitution of Iran, under the concept of Vilayet-e Faqih. Ghannouchi intended to say that this concept is a wrong concept which is a newly invented concept that is not accepted (Ghannouchi, 2015: 188-192).

The second group raised the argument that Imamate is a matter of representation of God; there is no such type of contract between Imam and people because Imam isn't sovereign in an Islamic state, where sovereignty is belonged to Allah. The Imam is giving service to the people only. In this state in one side Allah, and in another side ruler and ruled where this ruler and ruled is following the path of Allah and protecting contract with him. The people will obey the elected ruler otherwise they will be evaluated to come in the opposite of Shariah. In Islam i.e. Islamic aspect of legislation, rules and regulations adopted from the text. In this perspective, Ghannouchi intended to argue that the contract doesn't mean the rules (legislation), but it is related to become ruler (Ghannouchi, 2015: 193).

The third group raised the issue that the state is not a matter of social need as stated in the Western political thought but it is a matter of text (Nass). It also adopted from the Shia Imamate theory. The Khawarij people are also in the same opinion. In this perspective, Ghannouchi argued that state is a matter of social need of human beings. He stated several verses of the Quran where Allah mentions a lot of aspects of human being where it is indicated that the state is a social need.

$\checkmark$ The nature of the Islamic government

With discussing this political aspect of Shura, Ghannouchi intended to discuss the nature of Shura based Islamic government and compare with other types of government. He started within the Quote of Hazrat Ali where he stated 
that leader should exist to the people both in good or bad time (all time) to govern them. Government or authority is a general need of the people. He argued that Islam is a combination of faith (Akidah), deeds (Ibadat), characters (Akhlak) and Shariah (Islamic law). For preaching activities (Da'wah) of Islam, and to continue its existence it is necessary to be a state. Ghannochi here argued that in this meaning there is no misunderstanding in this concept. He again made clear his position that to make a contract doesn't mean the context of sharia is not important or second class important. He stated the policy of Usul, "to complete the obligatory, the means of actions is also obligatory" (Ghannouchi, 2015: 195).

Finally, he argued that from all aspects the Islamic government is a civilian government where the Ummah is the basis for state authority. In this system, $B a$ 'yah is the fundamental element for the application of Islamic state which means the people will. It is the fact for the candidacy of Imam. So, this $B a$ 'yah may offer a system of election in terms of modern democracy. Finally, this system demands a Shura based government without any debate (Ghannouchi, 2015: 195-196; 2013; 2010).

Here Ghannocuhi intended to compare three types of the state i.e. Theocratic, democratic and Islamic democratic to understand the position of Shura i.e. Ummah more clearly. He mentioned there types of state with mentioning the position of Ummah (society); "A. Ummah in terms of theocratic perspective; Allah- Government- Society: B. Ummah in terms of Western Democratic perspective; Society- Government: C. Ummah in terms of Islamic democratic perspective; Allah-Society-Government" (Ghannouchi, 2015: 225).
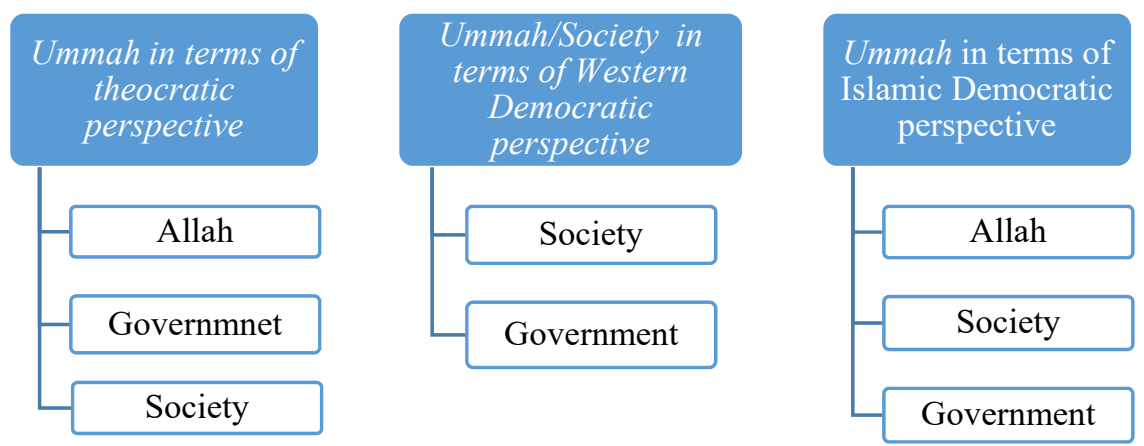

Figure- 1: Rachid Ghannouchi's perception of Ummah's position in three types of state (Author's design)

\subsubsection{The Economic Aspect of Shura}

Here Ghannouchi intended to argue that Shura is not only the abstract matter for governing but it is a practical way to show the right path for decreasing social discrimination. He mentioned from chapter al-Hashr, "It will 
not be a perpetual distribution among the rich from among you" (as translated by The Noble Quran, 2016, 59: 7)

Ghannouchi argued that Islam made a balance between ownership and social responsibilities. Islam provides full freedom to the owner to achieve goods and money with social responsibilities (paying Zakah for poor people). In the meaning of ownership Islamic economics is more near to the liberal and market economy. But the difference is the targets, attitudes, and morals.

\subsubsection{Educational and Cultural Aspects of Shura}

Ghannouchi argued that Shura ensures the participation of the abundance of knowledge. In Islam, acquiring knowledge is obligatory for Muslim. Ghannouchi argued that Islam made easy the way of acquiring knowledge and ordered the Muslims to be rational and not to hide the knowledge (when necessary). Islam ordered to make Ijtihad within knowledge and rationality without biasness. Within this way, Islam provides a wide range of the research facility to search the solution of contemporary issues. As a result in this aspect, Shura ensure more freedom for people.

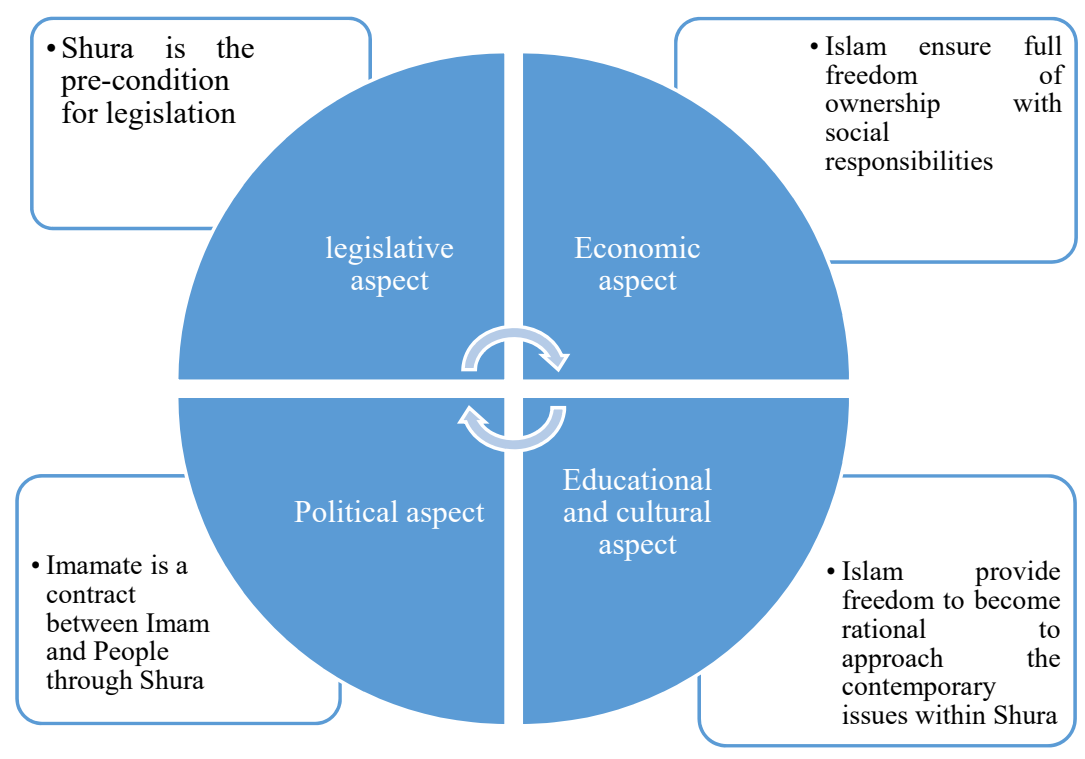

Figure-2: Different aspects of Shura in Ghannouchi's writing (Author's design).

4. The Arab Spring and the Ghannouchi's Perception of Shura

Arab spring brings a significant change in the Middle East and North Africa, particularly the autocratic rulers as Zine el-Abedine Ben Ali, Hosni Mubarak, and Muammar al-Gaddafi has been dismissed from the power. A significant political change has been occurred in Morocco, Egypt, and Tunisia, where Islamist parties, notably PJD, Freedom, and Justice Party, and Ennahda, 
have come to power. However, the Arab Spring in Egypt transformed into Arab summer within one year because of General Sisi's Military Coup. Besides Egypt, the experience of the Arab Spring in Syria, Yemen, and Libya wasn't good in terms of changes of autocrats. Several internal disorder and humanitarian crisis is continuing. However, in Tunisia, Ennahda won the majority seats in parliament and formed a coalition government with liberal secularist parties. In 2012, the coalition government initiated a constitution accepted by majorities MPs as 200 MPs voted in favor of the new constitution, 12 MPs against, and four abstaining among 217 MPs legislative (Arieff and Humud, 2014: 3). This constitution didn't adopt Sharia, but it was a liberal democratic constitution with maintaining its Muslim identity. As described in the article 2 , and 3 of the constitution to describe its identity,

"Tunisia is a civil state based on citizenship, the will of the people, and the supremacy of law (this article might not be amended). The people are sovereign and the source of authority, which is exercised through the peoples' representatives and by referendum" (Constitute, 2019: 3).

It ensures several fundamental rights and freedoms for the citizen. As article 6 of the constitution, "freedom of conscience and belief" along with gender equality (article 21), right to life (article 22), human dignity (article 23), right to privacy (article 24), right to fair trial (article 27), freedom of expression and information (art. 31-32), right to academic freedom (article 33), right to strike and trade union (article 36) and other rights as property right, health care right, right of work, right to culture (Constitute, 2019; Arieff and Humud, 2014: 4; Rahman, 2021b). Within such liberal nature, it also ensures its Muslim identity in several places of the constitution repeatedly described this issue. For example, article one of the constitutions stated that the state religion is Islam. Article six guaranteed that the state is the religion's guardian, and article 74 stated that only Muslims could run for president. As mentioned,

"Every male and female voter who holds Tunisian nationality since birth, whose religion is Islam shall have the right to stand for election to the position of President of the Republic" (Constitute, 2019).

However, this constitution is more open for all groups where the Sharia law hasn't taken place. Although a group of parliamentarians, even from Ennahda, had called for the inclusion of Sharia, Ghannouchi overruled their opinion. He often stated that "Tunisia is more important than Ennahda" (Lubben, 2016). Following this way, he and Ennahda tried to adopt a powersharing culture with the establishment, more specifically with the secularist block, which is continuing till now. He strongly argued for this power-sharing culture for resistance against dictatorship. As stated before, Ghannouchi's realpolitik inspired him to develop democratic values in terms of the long autocratic role which he and his party faced along with other Islamists movement in all over the world, particularly in the MENA region. Ghannouchi 
intended to save the Tunisian revolution (Arab Spring) from any bad situation like Egypt, Syria, Libya, or Yemen. As he stated,

"We advise all Islamists in the region to be more open and to work with others and to look for a consensus with others, because without national unity, without national resistance against dictatorship, freedom cannot be achieved" (Middle East Eye, 2016).

Accordingly, the activities of extreme Salafists was increasing significantly after the Arab Spring. Several terrorist attacks took place in Tunisia, mainly attack an arts exhibition in La Marsa in June 2012 (Wolf, 2013). On the other side, Tunisian extreme Salafist participation with ISIS also increased. That was the concerning issue for Ghannouchi and Ennahda's leadership to develop power-sharing culture. Within this power-sharing process, Ghannouchi intended to forward a more liberal culture in Tunisia to maintain its conservative Muslim culture. In this context, Ennahda tried to compare its policy with the policy of the Justice and Development Party (AK Party) in Turkey (Wolf, 2013; Göksel, 2014; Bartal, 2020). Ghannouchi himself often stated the AK Party as their model for politics. As cited by Göksel from Ghannouchi's interview,

"Taking lessons from Turkey": "Turkey is a model country for us in terms of democracy. There are very good relations between Turkey and Tunisia, and I hope there will be a proper environment in the future where we could foster those relations" (Göksel, 2014).

As stated before, Ghannouchi's power-sharing with the secularist block didn't initiate the Sharia law in the constitution. Here, Ghannouchi probably intended to concern the issue of development or developing public life first within liberal democracy (Kaya, 2018; Rahman, 2021a; Rahman, 2021b). In addition to this, the values of democracy are necessary to establish in all areas to decline the autocracy or dictatorship. Wolf (2013) stated that Ghannouchi doesn't simply mean the Sharia as the issues of some law of punishment rather a set of values, justice, brotherhood, liberty and so on. For initiating the traditional aspect of Sharia, i.e. the punishment laws, it is necessary to ensure justice first, and people should understand the aspect of Islamic norms and values. As stated by Wolf,

"Ghannouchi is against imposing Islamic law on a society in which 'many people do not understand it'. He insisted that 'in a democratic state, the parliament has to reflect the society,' stressing that 'Ennahda does not want Bourguiba and Ben Ali's top-down approach of imposing their ideology and strategy on the Tunisian people" (wolf, 2013).

With this long transition in realpolitik, Ghannouchi till remains his importance on Shura. Bartal (2020) stated from Ghannouchi that this transformation (power-sharing) might not necessarily be based on Islamic sharia law. However, it must be based on an essential foundation of an Islamic government, namely shura or the authority of the Umma (Bartal, 2020). Further, 
Ghannouchi was asked about his policy regarding Shura just after the transformation of Ennahda, he answered,

"Our party is democratic. Decision making in the party is not individual. Decisions are made by institutions. We would like to institutionalise any decision making concerning the public interest. So we are very keen to fight against any sort of dictatorship, inside the party, or in the wider political system" (Middle East Eye, 2016).

Besides this, the 10th party conference of Ennahda made a significant change within party policy, devoted to clarify the relation between the party's religious mission $\left(D a^{\prime} w a h\right)$ and its political mission. As from Ghannouchi deliver his speech toward its transformation in the 10th conference, "we are leaving political Islam to enter into Muslim democracy,' he said. 'We are Muslim democrats who no longer call for political Islam" (as cited McCarthy 2018: 1). Finally, the leaders of Ennahda now intend to clarify their party as a democratic party with an Islamic reference or the party as Muslim democracy. They often highlights their party as the parallel with Christian-Democratic European parties like Germany's Christian Democratic Union (CDU), seemed to be the easiest way to signify Ennahda as a political party bringing together both democratic principles and religious values (Ounissi, 2016: 7; Rahman, 2021b).

Ghannouchi is criticized both from the Islamist and the establishment. The Islamists, particularly the mainstream Islamist parties even the conservatives from his party. Along with this, he is extensively criticized by the Salafist, i.e. the extremist. This group criticized Gahnnouchi's initiative toward democracy is totally a Western liberal concern in Islamic political thought. Perhaps the criticism of this group is vital in terms of Islamic political thought where he is criticized for following the Western or being more liberal in every aspect (Rahman, 2021b).

In this perspective, Ghannouchi intended to clarify the aspect of Hikmah which according to him, a lost property (value) of Muslims (Ghannouchi, 2015: 111). In this perspective, the approach of Maqasid is also needed to mention here. In Usul al- Figh perspective, Ilm al-Maqasid is an essential aspect of Usul where the object of the task is a crucial matter. For instance, AshShatibi (d. 1388) was the first Muslim theorist who intended to bring the issue of Maqasid systematically within his masterpiece, Al-Muwafaqaat fi Usool alSharia. He defined Maqasid al-shariah as "the attainment of good, welfare, advantage, benefits, and warding off evil, injury, loss of the creatures" (Khan \& Ghifari, 1992). Ibn Ashur was the Modern pioneer of the Maqasid approach, who also was a Tunisian. According to his Maqasid approach, any rule or matter related to Shari'a must be taken by its high aim where five basic elements should be focused; Religion or belief (Din), Life (Nafs), Mind (Aql): Offspring (Nasab): Wealth (Mal) (Ibn Ashur, 2006; Maklik and Shukri, 2018). Ghannouchi's perception of politics i.e. Muslim democracy within Shura is for 
the well-being of Ummah which extensively consider the present context within a realpolitik perspective (Ghannouchi, 2015: 110-112).

On the other hand, previous Ben Ali government and Tunisian establishment criticized and intended to establish him as extremist and violent Islamist, particularly in the time of before Arab Spring. However, the criticism of this second group has been eliminated partially through Ghannouchi's initiatives of power-sharing with liberalist and secularist.

\section{Findings and Conclusion}

With above discussion, it is apparent that Ghannouchi put Shura in the center to define his conception of state. He identified two principles of Islamic state as text and Shura where Shura is the most important principle because the aspects of text implemented by Ummah as the vicegerent of Allah through Shura. He stated the legislative, political, economic and educational aspects of Shura. In legislative aspect, Shura is the prime issue for legislation. Here, Shura included the opinion of whole Ummah, not only a group of people like Ulama or Jurist as it argued by classical theorist. He mentioned three ways by which the Shura may implement; firstly by general election or referendum in big decisions like electing the president; secondly, by expertise bodies in a specific task who will represent the whole Ummah; finally, the Ulama for controlling the matter of Sharia who also will represent the whole Ummah.

In political aspect, Shura is the necessary element for the birth of state. $\mathrm{He}$ argued that Imamate in Islamic state is a matter of contract rather than coercion. He further included Imamate is a contract between Imam and the Ummah. In this perspective Islamic state is similar to the social contract theory. He mentioned previous researches here that Imamate is a matter of contract even it traced before the social contract theory. He mentioned several examples from Islamic history where the caliphs had been elected by the opinion of people particularly the election Abu Bakar. Even, Ghannouchi stated the seeking contract (Ba'yah) from Aws and Khajraj to establish political authority in Medina under the Prophetic rule. So, here he intended to clear about his democratic notion of state. In his perception, Ummah is the center through Shura in Islamic state. Following this way, he argued that Islamic democratic state as Allah; society; State which is different from classical Islamist intellectuals according to them Allah; state; society as well as the concept pf Western democratic state as society; state.

In economic perspective Shura ensured the practical measure of democratic state not only an abstract matter by adapting Zakah System which made a balance between rich and poor. In Educational perspective, Shura showed the way to become rational with acquiring knowledge which has been made obligatory for Muslim.

Along with this theoretical perspective, Ghannouchi's movement toward democratic transition after the Arab Spring is also important here. Several 
transformations might occur in Ghannouchi's thought and politics of Ennahda but Shura remain as an important aspect of his perception.

Finally, Ghannouchi put Shura as the center of his political thought. Along with theoretical matter, he is practicing the aspects of Shura in real politics. Within this way, he argued for Muslim democracy. In the end, it might say that Muslim democracy through Shura has become a new model in Islamist's political thought especially after the Arab Spring.

\section{Reference}

Al-Mawardi, A. A. H. (1996). Al-Ahkam as-Sultaniyyah: the Laws of Islamic Governance. Trans. Asadullah Yate (London: Ta-Ha Publishers, 1996).

Arieff, A. and Humud, C. E. (2014). Political Transition in Tunisia, Congressional Research Service, Retrieved from: www.crs.gov (last accessed; 10.10.2020)

Bartal, S. (2020). Rached Ghannouchi's test: Political Islam and democracy in Tunisia. African Studies, 1-15.

Black, A. (2011). The History of Islamic Political Thought; from the prophet to the present. Edinburg: Edinburg University Press

Constitute (2014). Tunisia's constitution of 2014. constituteproject.org, Retrieved from: https://www.constituteproject.org/constitution /Tunisia 2014.pdf (last accessed; 10.10.2020)

El-Ghazali, A. H. (2011). The way to the revival of Ummah A study of the thinking of Imam al Banna. Cairo; Al Falah Foundation

Elo, S. and Kynga, S.H. (2008). The qualitative content analysis process. Journal of Advanced Nursing 62(1), 107-115

Enayet, H. (1982). Modern Islamic Political Thought. London and Basingstoke; The Macmillan Press Ltd

Esposito, J. L. and Piscatori. J.P. (1991). Democratization and Islam. The Middle East Journal 45 (3), 427-440

Ghannouchi, R. (2013). The state and religion in the fundamentals of Islam and contemporary interpretation. Contemporary Arab Affairs, 6(2), 164-171.

Ghannouchi, R. (2015). İslam Devletine Kamusal Özgürlük. Translated byOsman Tunç, İstanbul: Maya Yayınları

Ghannoushi, R. (2010). Islamic Movements: Self-Criticism and Reconsideration. M. Abu-Rabi' (Ed.), The Contemporary Arab Reader on Political Islam, London : Edmonton: Pluto Press.

Göksel, O. (2014) Perceptions of the Turkish Model in Post-Revolutionary Tunisia, Turkish Studies, 15:3, 476-495, DOI: $10.1080 / 14683849.2014 .954747$

Hourani, A. (1983), Arabic Thought in the Liberal Age, 1798-1939, 2nd edition, Cambridge, Cambridge University Press

Ibn Ashur, M. A. T. (2006). Ibn Ashur Treatise on Maqasid al-Shari'ah. The Other Press. 
Ibn Taymiyyah (2000). The Political Shariyah on Reforming the Ruler (translated by Dr Umar Farrukh)", UK; Dar ul Fiqh

Kaya, A. (2018). Gannuşi'nin "Siyasetsiz" Siyaset Felsefesinin Kritiği. Insan ve Toplum, 8(1), 115.

Khan, M. F., \& Ghifari, N. M. (1992). Shatibi's objectives of Shariah and some implications for consumer theory. Readings in Islamic economic thought: selected readings, 176-202.

Krippendorff, K. (2004). Content analysis: An introduction to its methodology (2nd ed). Thousand Oaks, CA: Sage.

Lübben, I. (2016). 10th conference of the Tunisian Ennahda Party; Farewell to political Islam? Qantara.de, Retrieved from; https:/en.qantara.de/content/10th-conference-of-the-tunisian-ennahdaparty-farewell-to-political-islam (last accessed; 10.10.2020)

Malik, M., \& Shukri, S. F. M. (2018). From Political Islam to Democrat Muslim: A Comparison between Rashid Ghannouchi and Anwar Ibrahim. Intellectual Discourse, 26(1), 161-188.

Marzo, P. (2019). Critical junctures, path dependence and Al-Nahda's contribution to the Tunisian transition to democracy. The Journal of North African Studies, 24(6), 914-934.

McCarthy, R. (2018). Inside Tunisia's al-Nahda: between politics and preaching. Cambridge University Press.

Middle East Eye (2016). Rached Ghannouchi Q\&A: Thoughts on democratic Islam. Retrieved from: https://www.middleeasteye.net/news/rachedghannouchi-qa-thoughts-democratic-islam (last accessed: 09.10.2020)

Mulk, N. (1960). Siyar al-Muluk (siyasatnama), ed.Hubert Darke, New Haven: Yale University Press.

Okumuş, F. (2019). İslami hareketlerin "şûrâ" prensibi karşısındaki tutumu: ihvan ve nahda örneği, Retrieved from: https://katalog.marmara.edu.tr/veriler/yordambt/cokluortam/DB8762809B75-4345-A41B-786D9D3631B4/FAT\%C4\%B0H\%20OKUMU \%C5\%9E.pdf (Last accessed: 13.02.2021).

Ounissi, S. (2016). Ennahda from within: Islamist or "Muslim Democrat"? Brookings Institution Rethinking political Islam series, March 2016

Qaradawi, Y. (2004). State in Islam, Al Falah Foundation, Cairo.

Qutb, S. (2013). Social Justice in Islam, Translated by Mohammad Ali Gerami and Seyed Hadi Khosrowshahi. Qom: Institute of Boostane-e-Ketab (Center for Islamic Propagation Office of Qom Seminary)

Rahman, H. (2021a). Modern İslami Siyasal Düşüncede Devlet, Çizgi Kitabevi

Rahman, H. (2021b). The Perception of Muslim Democracy in the Political thought of Rachid Ghannouchi, The Academic Elegance, 8 (15), 361-376. Retrieved from https://dergipark.org.tr/tr/pub/akademik hassasiyetler/issue/61981/806905 
Shavit, U. (2010). Is Shura a Muslim form of democracy? Roots and systemization of a polemic. Middle Eastern Studies, 46(3), 349-374.

Tamimi A.S. (2001). Rachid Ghannouchi; A Democrat within Islamism. New York: Oxford University Press

Tamimi, A. S. (1997). Democracy in Islamic Political Thought. ENCOUNTERS-LEICESTER-, 3, 21-44.

The Noble Quran (2016), Website; https://quran.com/

Turabi, H. (1983) 'The Islamic State', In John Esposito (ed.) Voices of Resurgent Islam (pp. 241-51). Oxford: Oxford University Press.

Whyte, S. A. (2019). Advancing Shūrā: A Social Agent for Democratization. Islam and Christian-Muslim Relations, 30(3), 345-362.

Wolf, A. (2013) An Islamist 'renaissance'? Religion and politics in postrevolutionary Tunisia, The Journal of North African Studies, 18: 4, 560573, DOI: $10.1080 / 13629387.2013 .829979$

Zoubir, Y. H. (1998). Democracy and Islam in Malek Bennabi's Thought, The American Journal of Islamic Social Science 15: 1 